\title{
Pharmacogenetics in Acute Lymphoblastic Leukemia
}

\author{
Meyling H. Cheok, PhD [Research Associate] ${ }^{1}$, Nicolas Pottier, PharmD ${ }^{2}$, Leo Kager, MD \\ [Associate Professor of Pediatrics] ${ }^{3}$, and William E. Evans, PharmD [Director and Chief \\ Executive Officer] ${ }^{4}$
}

1Jean-Pierre Aubert Research Cent, INSERM U837, Genomics Core IRCL-IMPRT, Lille, France

2EA2679, Faculte de Medecine de Lille, Pole Recherche, Lille, France

3St. Anna Children's Hospital, Vienna, Austria

4Department of Pharmaceutical Sciences, Hematological Malignancies Program, St. Jude Children's Research Hospital, Memphis, TN, USA (William.evans@stjude.org) and the Pharmacogenetics of Anticancer Agents Research Group in the Pharmacogenetics Research Network

\begin{abstract}
Progress in the treatment of acute leukemia in children has been remarkable, from a disease being lethal four decades ago to current cure rates exceeding $80 \%$. This exemplary progress is largely due to the optimization of existing treatment modalities rather than the discovery of new antileukemic agents. However, despite these high cure rates, the annual number of children whose leukemia relapses after their initial therapy remains greater than that of new cases of most types of childhood cancers. The aim of pharmacogenetics is to develop strategies to personalize treatment and tailor therapy to individual patients, with the goal of optimizing efficacy and safety through better understanding of human genome variability and its influence on drug response. In this review, we summarize recent pharmacogenomic studies related to the treatment of pediatric acute lymphoblastic leukemia. These studies illustrate the promise of pharmacogenomics to further advance the treatment of human cancers, with childhood leukemia serving as a paradigm.
\end{abstract}

\section{DEFINITION AND AIMS OF PHARMACOGENOMICS}

The effects of antileukemic drugs are determined by the interplay of numerous gene products that influence each medication's pharmacokinetics (drug metabolism or disposition) and pharmacodynamics (drug efficacy or toxicity). Specifically, pharmacogenetics focuses on genetic variation of drug metabolizing enzymes, targets and transporters and how these genetic variations interact to produce specific drug related phenotypes. Furthermore, potential genetic markers may serve to functionally sub-classify patients for their disease and therefore influence the nature and intensity treatment. These genetic markers may indicate novel drug targets or modifiers that may positively influence drug effects and toxicity, (such as reverse drug resistance and increased cellular uptake) ${ }^{1}$. Ultimately, the intent of pharmacogenetics is to develop polygenic models that accurately predict drug response and toxicity for individual patients, and to use these models to prospectively personalize treatment regimens with the goal of enhancing efficacy and safety through better understanding of the patient's pharmacogenetic characteristics (Figure 1). Of note, pharmacogenomics is often considered synonymous with

Correspondence to: William E. Evans.

Publisher's Disclaimer: This is a PDF file of an unedited manuscript that has been accepted for publication. As a service to our customers we are providing this early version of the manuscript. The manuscript will undergo copyediting, typesetting, and review of the resulting proof before it is published in its final citable form. Please note that during the production process errors may be discovered which could affect the content, and all legal disclaimers that apply to the journal pertain. 
pharmacogenetics, but this latter term is increasingly used in the context of polygenic models that describe specific drug response phenotypes.

\section{PHARMACOGENOMIC TOOLS AND METHODS}

\section{Genomic variations}

Common genetic variations include single nucleotide polymorphisms (SNPs), genomic insertions and deletions, and genetic copy number variation (CNV). Tumor-specific genetic changes include inter-chromosomal translocations, loss of heterozygosity (LOH), and uniparental disomy (UPD). Epigenetic changes, such as silencing of gene expression via DNA hypermethylation can also influence drug effects, and aberrant methylation of $\mathrm{CpG}$ islands is a common feature of cancer cells.

The most frequent inherited sequence variations are SNPs, which constitute about $90 \%$ of all human genome variation and occur every 100 to $300 \mathrm{bp}$. By definition a SNP is present in at least $1 \%$ of the population. It is now estimated that about 7 million SNPs exist in humans with a minor allele frequency of $>5 \% 2,3,4$. The main public SNP database dbSNP

(http://www.ncbi.nih.gov/SNP/) currently contains more than 12 million human SNPs (build 129 of which $50 \%$ are validated). Only a small proportion (approximately 60,000) of the known SNPs are located within coding regions of genes, and only about 30,000 of them cause amino acid changes in expressed proteins (so called non-synonymous SNPs) ${ }^{5}$. Amino acid changes have the potential to alter the function of the encoded protein ${ }^{6}$. Of importance, for the ATPbinding cassette transporter ABCB1, a 'silent' or synonymous SNP (which does not cause an amino acid substitution) was recently found to affect protein folding and function of the encoded transport protein 7 . Aa SNP in the micro RNA binding site of the methotrexate target dihydrofolate reductase (DHFR) has been associated with MTX resistance ${ }^{8}$.

SNPs in the same region of DNA form haplotypes (usually $<50 \mathrm{~kb}$ apart from each other) that are typically inherited together. The human genome is organized in haplotype blocks with high linkage disequilibrium (LD): regions with a high level of concomitant inheritance that are separated by regions of low LD (regions with low level of concomitant inheritance) $)^{9,4}$. Therefore, SNPs that are in strong LD with a disease phenotype or a drug-response phenotype can point to the position on the chromosome where a susceptibility gene or a functional SNP is located, even though the SNPs themselves may not cause the phenotype ${ }^{10}$. By studying LD across the genome, the International HapMap Project has constructed a high-density haplotype map of the human genome, an important tool for studying complex phenotypes like disease risk and drug response in different racial populations ${ }^{11}$.

Recent genotyping methods have greatly increased throughput and reduced the costs of obtaining relevant genotype information from genomic DNA and of DNA from tumor tissue. Traditional methods like gel electrophoresis-based methods are PCR coupled with restriction fragment length polymorphism analysis (PCR-RFLP), and are also useful for in depth validation analyses. Typical modern high-throughput methods employ fluorescent dye-based technologies. Lastly, high through-put assays DNA chip-based and DNA bead-based array genotyping technologies have been greatly improved recently, and innovations are still emerging $12,13,14,15,16$. The greatest challenge however, remains how to utilize these methods to elucidate significant genotype-phenotype (e.g., drug response) relationships, many of which are complex and multigenic ${ }^{17,1,18,19}$.

Genetic DNA copy number variation (CNV) between normal individuals amounts to $4 \mathrm{Mb}$ $(1 / 800 \mathrm{bp})$ of genetic difference, and at less conservative estimates is in the range of 5-24 Mb. $\mathrm{CNVs}$ account for more nucleotide variation on average than do SNPs ${ }^{20,21}$. Gene copy number may be higher or lower in cancer cells. For example, the EGFR copy number can be higher in 
non-small cell lung cancer compared to normal tissue 22 , whereas genes involved in B-cell development and differentiation are commonly deleted in B-lineage ALL ${ }^{23}$.

More tumor-specific are inter-chromosomal translocations, especially in hematological malignancies, and these are being widely used for disease diagnosis, treatment stratification, and disease follow-up 24,25 .

In the context of oncogenesis, loss of heterozygosity ( $\mathrm{LOH})$ is common in many human cancers. An inactivating mutation in one allele of a tumor suppressor gene can occur in the parent's germline cells and be subsequently inherited by the progeny, creating heterozygosity for that allele. Loss of heterozygosity occurs when the remaining functional allele in a somatic cell of the offspring becomes inactivated by mutation or other genomic mechanisms (such as partial or complete deletion). Loss of expression of a functional tumor suppressor can be tumorigenic 26 .

\section{High Through-put Gene Expression and SNP Profiling}

The most commonly used high through-put techniques are gene arrays 27 . Workflows are standardized and often facilitated in specialized shared core facilities. Novelties include Illumina's Human1M BeadChip ${ }^{\circledR}$ which interrogates more than 1.1 million SNPs loci per sample, and is able to detect known and novel CNV regions. The uniform genome-wide coverage results in a median spacing between markers of $1.5 \mathrm{~kb}$ (www.illumina.com). The Affymetrix GeneChip ${ }^{\circledR}$ Genome-Wide Human SNP Array 6.0 features 1.8 million genetic markers, including more than 906,600 single nucleotide polymorphisms (SNPs) and more than 946,000 probes for the detection of copy number variation (www.affymetrix.com).

miRNAs are 19-24 nucleotide long noncoding RNAs that are found in almost all species. Recent significant advances in understanding the physiological functions and differential expression patterns of miRNAs have been related to many disease states, including human cancer. miRNAs represent an interesting class of genes with potential utility in diagnosis, prognosis, and treatment ${ }^{28}$. Any array design technology has to be considered carefully because of the nature of microRNA (i.e., short length and small abundance) ${ }^{29}$.

\section{Bioinformatics and Systems Biology}

Pharmacogenetics is a good example of translational research that requires integration of diverse disciplines such as biology, medicine, pharmacology, genetics, and bioinformatics. Bioinformatics, short for biomedical informatics, involves multiple disciplines as well (pplied mathematics, statistics, informatics, computer science, artificial intelligence, chemistry and biochemistry), has been given prominence by the Human Genome Project. Bioinformativs has been instrumental in the evolution of pharmacogenetics to pharmacogenomics. This discipline includes generation, maintenance, and mining of typically large and diverse public and private databases. Particularly challenging for pharmacogenomics is the integration of genomic, biological, pharmacological, and clinical data to elucidate the genetic basis of complex polygenic drug response traits 30 . Important pharmacogenetic websites are listed in Table 1

Systems biology is a relatively new field that focuses on the systematic study of complex interactions in biological systems with the aim to develop mechanistic models of biological networks. A driving concept in systems biology is integration versus the traditional strategy of reduction to find mechanism. To be able to obtain, integrate and analyze complex data from multiple experimental sources, multiple strategies are commonly used (transcriptomics, proteomics, metabolomics, interactomics, biomics, and others) $31,32,33$. 


\section{Chemosensitivity and Genomics}

Malignant cells carry the same germline genetic polymorphisms as do normal cells; however, increased genetic instability of malignant cells can produce a relatively high frequency of additional mutations, which alter the biological characteristic of cancer cells (like drug resistance). For example, duplication of entire chromosomes is a relatively common event in ALL cells ${ }^{34}$. Some important sites of germline variations affecting cell growth include the replication apparatus, apoptosis and cell cycle proteins, cytoskeletal proteins, nucleic acids, and signal transduction elements. Most primary cancer cells retain expression patterns similar to their tissue of origin, but some genes appear to be more highly expressed in many different cancers $^{35}$. Finally, evaluation of experimetal findings should be carefully scrutinized, because cancer cell lines cultured in vitro may display substantially different gene expression patterns and biological characteristics than primary cancer cells in vivo 36,37 .

There is a paucity of literature describing comprehensive evaluations of genetic features that confer chemoresistance; however, multiple mechanisms of resistance are likely to be responsible for drug resistance within a tumor cell population. Contemporary methods (gene expression profiling, proteomics) in combination with bioinformatics and sytems biology show promise to facilitate more extensive, yet logistically feasible, studies to elucidate the underlying biological mechanistics influencing drug resistance.

\section{GENETIC POLYMORPHISMS INFLUENCING ANTILEUKEMIC DRUG METABOLISM AND DISPOSITION}

Essentially all of the major human drug-metabolizing enzymes that catalyze either the modification of functional groups on drug molecules (classified as phase I reactions) or the conjugation of drugs with endogenous substances to render them more readily excreted (classified as phase II reactions) exhibit genetic polymorphisms, and these polymorphisms influence drug metabolism and disposition ${ }^{38}$. Cytochrome P450 enzymes and quinone oxidoreductases are relevant examples of phase I enzymes. Important phase II enzymes include glutathione S-transferases (GSTs), thiopurine S-methyltransferase (TPMT), and UDPglucuronosyl transferase (UGT).

Recent pharmacogenetic studies have focused on comprehensive analyses, evaluating the net effect of a combination of SNPs in one or multiple candidate genes in a treatment-related context ${ }^{39,40,41,42}$. For example, 246 children with ALL were screened for 16 genetic germline SNPs in 13 candidate genes, and these were tested for association with outcome or antileukemic drug toxicity 41,42 . The GSTM1 non-null genotype to be significantly associated with increased relapse rate in high-risk (HR) patients. No genotypes were found to be predictive for outcome in the low-risk group 41,42 . Furthermore, four germline SNPs were significant determinants of antileukemic drug toxicity. During the induction phase of ALL therapy, the predominant drug metabolism pathway is via CYP3A, and variations in this pathway (the vitamin D receptor $(V D R)$ intron $8 \mathrm{GG}$ ([hich regulates $\mathrm{CYP} 3 \mathrm{~A} 5$ and $\mathrm{ABCB} 1]$ and the CYP3A5 GG [which is correlated to lower CYP3A5 activity]), were related to gastrointestinal toxicity and infection. During the consolidation and continuation phase, when antifolates predominated, the reduced folate carrier $(R F C) \mathrm{AA}$ or $\mathrm{AG}$ genotypes predicted gastrointestinal toxicity. Interestingly, in all three phases the UGT1A1 promoter repeat polymorphism (UGTIA1 7/7) predicted hyperbilirubinemia ${ }^{41,42}$. It is important to recognize that these genetic polymorphisms may significantly associate with a specific drug response phenotype in the context of one treatment protocol but not in another protocol for the same disease. Correlations may be related to the nature of other chemotherapy administered, to the dose or schedule of medications, to the nature of supportive care, or to the scrutiny with which a specific drug effect (especially toxicity) is measured at different treatment centers. It is important to 
confirm the association of a specific genetic polymorphism with a specific drug effect in a new treatment context, before the putative relationship is routinely employed in treatment decisions.

\section{GENETIC ABERRATIONS INFLUENCING ANTILEUKEMIC DRUG RESPONSE AND ADVERSE EFFECTS}

\section{Thiopurines}

The thiopurine antimetabolites mercaptopurine (MP) and thioguanine (TG), analogues of the purine nucleosides hypoxanthine and guanine, are key components in childhood ALL treatment protocols. MP or TG is used during induction consolidation treatment as well as in maintenance therapy. After uptake via nucleoside transporters, these medications are metabolized into active cytotoxic thioguanine nucleotides (TGNs) and cytotoxicity occur mainly by incorporation of TGNs into DNA or RNA resulting in cell cycle arrest and apoptosis 43 .

TPMT, a ubiquitously cytosolic enzyme, catalyzes the S-methylation of thiopurines, and the TPMT pathway is the main mechanism of thiopurines intracellular inactivation in hematopoietic tissues. Thus the balance between TGNs and inactive metabolites in hematopoietic cells is regulated predominantly by TPMT. Large inter-individual differences in TPMT activity were recognized as an inherited trait over 25 years ago, and more recently the genetic polymorphisms in the TPMT gene that are responsible for this pharmacogenetic trait have been identified and characterized ${ }^{44}$. Three variant alleles $(T P M T * 2, T P M T * 3 A$ and $T P M T * 3 C$ ) account for more than $95 \%$ of the inhierited variability in TPMT enzyme activity $45,46,47$. About $90 \%$ of the population have two wild-type TPMT alleles (TPMT*1) and thus "normal" enzyme activity; about 5-10\% of individuals inherit one wild-type TPMT allele and one non-functional allele and have intermediate activity; and about one in 300 persons inherit two non-functional alleles and is therefore TPMT-deficient ${ }^{48}$.

Clinical interest in TPMT pharmacogenetics is based on numerous studies showing that TPMT genotype or phenotype identifies patients at high risk of hematopoietic toxicity after thiopurine therapy 49 . TPMT-deficient patients treated with conventional doses of thiopurines are predisposed to drug-induced complications by accumulation of excessive intracellular concentrations of TGNs $50,51,52$. These patients require a reduction of more than $90 \%$ of the conventional dose $\left(75 \mathrm{mg} / \mathrm{m}^{2} /\right.$ day $)$. Moreover, there is evidence that ALL patients with at least one TPMT-variant allele may respond better to thiopurine therapy when compared to those with two wild-type TPMT alleles ${ }^{43}$. TPMT deficiency also has been associated to an increased risk of epipodophyllotoxin-related acute myeloid leukaemia ${ }^{53}$ or irradiation-induced brain tumors 54 .

Whether patients with one functional allele would benefit from dose reduction is less clear. Although heterozygous TPMT patients treated at conventional doses $\left(75 \mathrm{mg} / \mathrm{m}^{2}\right.$ per day) are at higher risk of dose-limiting hematopoietic toxicity ${ }^{52}$, those treated according to BFM protocols $\left(60 \mathrm{mg} / \mathrm{m}^{2}\right.$ per day) did not exhibit a higher rate of hematopoietic toxicity and would therefore not be expected to benefit from dose reduction ${ }^{55}$. In addition, TPMT genotype was associated with a better early response to ALL chemotherapy (that included MP), measured as minimal residual disease (MRD) at day 78 following ALL induction and consolidation therapy ${ }^{55}$. Heterozygous TPMT patients had a 2.9 -fold lower risk of detectable MRD; this finding was consistent with higher systemic exposure to thiopurines due to lower MP metabolism. Long-term outcome studies are necessary to clarify whether MP dose escalation in the large cohort of TPMT-homozygous wild-type patients will yield greater efficacy in protocols that routinely use lower MP doses $\left(50-60 \mathrm{mg} / \mathrm{m}^{2} /\right.$ day $)$. 


\section{Methotrexate}

The antifolate methotrexate (MTX) is an essential component of therapy in nearly all treatment protocols for childhood ALL. Although the optimal dosage is still under active investigation, high-dose MTX (HDMTX) is commonly given as consolidation therapy, and low-dose oral MTX (LDMTX) is given in continuation therapy in most childhood ALL treatment protocols.

Uptake of MTX into ALL cells is primarily mediated by RFC (SLC19A1), whereas efflux of MTX is mediated by ATP-binding cassette transporters (ABC-transporters) $56,57,58$. Once inside the cell, MTX is quickly converted into poly ( $\gamma$-glutamate) forms (MTXPGs), a reaction catalyzed by folylpolyglutamate synthetase (FPGS ${ }^{59}$. Compared to the parental drug, MTXPGs (especially long-chain MTXPGs) are retained longer in cells because they are not readily effluxed by ABC-transporters 60,61 . The ability of ALL cells to form and accumulate MTXPG has been shown to influence treatment response and outcome in childhood ALL ${ }^{62}$, 63,64

MTX exerts its cytotoxic effects by inhibition of dihydrofolate reductase (DHFR), whereas MTXPGs also target other folate-depedent enzymes such as thymidylate synthase (TYMS) or glycinamide ribonucleotide transformylase (GART). Inhibition of key enzymes of de novo purine synthesis and pyrimidine synthesis leads to the interruption of biosynthetic pathways that are critical for DNA synthesis, DNA repair, and cell replication, and cause cell death 60 , 61 . MTXPGs can be retroconverted to MTX in intracellular lysosomes via the enzyme gammaglutamyl hydrolase $(\mathrm{GGH})^{6}$.

MTX pharmacokinetics exhibit a large inter-individual variability that is still incompletely understood, manifest in patients with normal renal and liver function and sufficiently hydrated. Of note, a severe impairment in MTX excretion in an adult lymphoma patient was reported in association with a heterozygous $1271 \mathrm{~A}>\mathrm{G}(412 \mathrm{Arg}>\mathrm{Gly})$ mutation in the $A B C C 2$ gene; functional studies confirmed reduced function of the transporter protein encoded by this variant allele $^{67}$. In a subsequent study, genetic polymorphisms of $A B C C 2$ was assessed as they influenced high-dose MTX pharmacokinetics in children with ALL. In this small group of patients, the frequent $-24 \mathrm{C}>\mathrm{T} \mathrm{rSNP}$ had a sex-specific impact on MTX kinetics ${ }^{68}$. If confirmed in larger cohorts, polymorphisms in $A B C C 2$ might help to identify patients at high risk for impaired MTX excretion.

The enzymes 5,10-methylenetetrahydrofolate reductase (MTHFR) and TYMS are key in the folate pathway, and genetic variants of both TYMS and MTHFR could influence MTX therapy in certain contexts. MTHFR catalyzes a reaction that balances the cellular availability of 5,10methylene-tetrahydrofolate (THF) to 5-methyl-THF. THF is important for thymidylate and purine synthesis, whereas 5-methyl-THF is important for methylation reactions. A decrease of cellular 5,10-methylene-THF levels can result in uracil misincorporation into DNA, subsequent DNA damage, and thus an increase in MTX cytotoxicity. Therefore, functionally relevant polymorphisms in MTHFR were investigated for their contribution to variation in MTX response. Consistent with an earlier study 69 , an analysis of 520 children with ALL who were treated on CCG-1891 protocol showed that patients who carried the MTHFR C677T variant allele, which decreases the enzymatic activity, had significantly higher risk of ALL relapse ${ }^{70}$. Whether MTHFR polymorphisms might be more important when MTX is given without leucovorin rescue remains to be elucidated ${ }^{71}$.

TYMS encodes an enzyme that converts deoxyuridylate to deoxythymidylate, and deoxythymidilate is essential for DNA synthesis. Inhibition of TYMS by MTXPGs results in depletion of thymidine and causes DNA damage and cell death. Because MTXPG inhibition of TYMS is stochiometric, functional polymorphisms that alter the level of TYMS protein expression may alter MTX effects. The association between variants in TYMS and treatment 
outcome was investigated in 205 children with ALL treated on Dana-Farber Cancer Institute (DFCI) protocols. Patients who were homozygous for a triple (3R) 28 bp repeat element (which is associated with higher TYMS expression) had significantly higher risk of relapse or event ${ }^{72}$, and this finding was corroborated in a subsequent investigation at the same institution. In a case-control study, however, investigators from the Berlin-Frankfurt-Muenster (BFM) group failed to find an association between TYMS 3R variants and outcome in 80 children treated on ALL BFM-86 and ALL BFM-90 protocols ${ }^{73}$. Differences in MTX dosages between BFM protocols (four times $5 \mathrm{~g} / \mathrm{m}^{2}$ MTX) and Farber Cdenter protocols (single dose of $4 \mathrm{~g}$ / $\mathrm{m}^{2}$ MTX) may explain in part these conflicting results. Two recent investigations examined the combined effects of different polymorphisms in several candidate genes in children with ALL who were treated on DFCI or St. Jude Total XIIIB protocols: patients who carried the TYMS 3R/3R genotype (high-risk patients in Total XIIIB) had poorer outcomes ${ }^{74,42}$. Of note, neither in St. Jude Total XIIIB nor in DFCI patients were TYMS polymorphisms associated with more toxicity 39,41 , and an increase of MTX dosage may be a strategy to improve outcome in patients who carry the TYMS 3R/3R genotype and are treated on similar protocols.

Recently, candidate gene and genome wide approaches were used to elucidate genomic determinants of MTXPG accumulation ${ }^{75}$ and MTX cytotoxic effects in vivo ${ }^{76}$. MTXPG levels in ALL cells were found to differ significantly among major ALL subtypes, with three ALL subtypes (E2A-PBX1, TEL-AML1, and T-ALL) having low MTXPG accumulation.

Furthermore, genomic determinants associated with subtype-specific differences in MTXPG level differed in these major ALL subtypes. For example, ALL cells carrying the E2A-PBXI fusion gene were found to have the lowest expression of the major MTX import transporter SLC19A1 and correspondingly accumulated the lowest MTXPG levels in vivo ${ }^{75}$. It is likely that the identified impaired MTX transport into E2A-PBX1 ALL cells can be overcome by high-dose MTX infusions. Notably, clinical trials with excellent treatment results for $E 2 A$ $P B X 1$ ALL featured HDMTX consolidation therapy 77,78 . Patients with T-ALL and TEL$A M L 1$-positive ALL exhibited significant differences in the expression of other genes (low FPGS and high ABCC1 in T-ALL, versus high expression of ABCG2 export transporter in TEL-AML1 ALL) ${ }^{75}$. These findings suggest that patients with T-ALL and TEL-AML1positive ALL may also benefit from high-dose MTX, but the different underlying mechanisms suggest that the optimal dosage of HDMTX differ in these subtypes of childhood ALL.

In a subsequent investigation, a genome-wide assessment of gene expression in ALL blast cells was correlated with the in vivo response to MTX therapy in children with ALL; 48 genes (including TYMS and DHFR) were identified whose expression was significantly related to the reduction of circulating leukemia cells ${ }^{76}$. This measure of initial MTX in vivo response and the associated gene expression pattern were also predictive of long-term disease-free survival.

A naturally occurring SNP $829 \mathrm{C} \rightarrow$ T near the miR-24 binding site in the 3'UTR of DHFR altered miR-24 function and caused increased DHFR expression and MTX resistance ${ }^{8}$. Another study associated polymorphisms in DHFR with increased expression and lower eventfree survival ${ }^{79}$.

In summary, new insights into the genomic basis of MTX resistance and inter-patient differences in MTX response point to novel strategies to predict and to overcome MTX resistance in childhood ALL. It is almost certain that the application of newer genome-wide strategies will reveal additional genomic determinants of MTX's disposition and effects in pediatric ALL.

\section{Glucocorticosteroids}

Synthetic glucocorticoids (GC), such as dexamethasone and prednisolone, are an part of curative combination chemotherapy regimens used worldwide to treat $\mathrm{ALL}^{80}$. Indeed, GC 
effectively induce G1 cell cycle arrest and extensive apoptosis in certain cells from the lymphoid lineage, including ALL cells 81,82 . Also, GCs have relatively few acute side effects and no major carcinogenic properties 83 . Of importance, early treatment response to GC is a significant prognostic indicator of long-term treatment outcome in ALL 84,85 and in vitro cellular GC resistance is associated to higher risk of treatment failure 86,87 .

GC enter cells by passive diffusion and bind to the intracellular glucocorticoid receptor (GR), a ubiquitously expressed member of the nuclear receptor superfamily. In the absence of ligand, the GR is held in an inactive cytosolic complex consisting of two molecules of heat shock protein 90 and several immunophilins, such as FKBP51. Upon ligand binding, the GC-GR complex translocates to the nucleus, where it regulates the expression of a plethora of genes via both DNA binding-dependent and DNA binding-independent mechanisms 88 . The transactivation and/or transrepression of downstream target genes ultimately result in the induction of apoptosis 83 .

Although GC resistance has been extensively studied, its molecular basis remains poorly understood in $\mathrm{ALL}^{89}$. Recently, to gain more insight into prednisolone resistance in ALL, in vitro sensitivity to prednisolone was used to identify gene expression patterns associated with GC resistance in primary leukemia cells 90 . ALL cells resistant to prednisolone have a distinct gene expression profile and provided new candidate genes associated to prednisolone resistance. Several of these new candidates genes were functionally confirmed as important determinants of prednisolone resistance $91,92,93$.

Based on a database of drug-associated gene expression profiles, an overlap was identified between the mTOR inhibitor rapamycin profile and the GC sensitivity profile; rapamycin induces sensitization of human ALL cell lines to GC-induced apoptosis via modulation of MCL1, an antiapoptotic protein from the BCL2 family 92 . This finding was consistent with previous observations of an association between over-expression of MCL1 and prednisolone resistance in primary ALL cells 90 . Moreover, in vitro data showed that modulation of MCL1 was specifically related to GC sensitivity. MCL1 appears an important determinant of GC sensitivity and combining rapamycin with GC may be useful in the treatment of ALL ${ }^{92}$. Furthermore, changes in gene expression induced by prednisolone treatment were analyzed in primary ALL cells, revealing three major pathways involved (MAPK, NF- $\kappa \mathrm{B}$, carbohydrate metabolism) 94.

Chromatin structure, by blocking access to the transcriptional machinery, mediates inhibition of gene transcription. Dynamic changes of chromatin structure are required for the activation of the gene transcription process and can be modulated in part by the SWI/SNF [these abbreviations need to be defined] complex through chromatin remodelling and nucleosome disruption. GR mediates the stimulation of SWI/SNF nucleosome disruption, thereby increasing accessibility of nucleosomal DNA to transcription factors $95,96,97$. Based on the identification of lower expression of SMARCB1, a core member of the SWI/SNF complex, as highly related to GC resistance in ALL cells, the expression of other SWI/SNF complex member subunits was assessed for their influence on GC sensitivity in ALL. Using primary ALL cells from two independent cohorts of newly diagnosed patients, decreased expression of key members of the SWI/SNF complex (SMARCA4, the functional ATPase domain; SMARCB1. a core member; and ARID1A and SMARCC2, both previously shown as physically interacting with the GR) was significantly associated with GC resistance 93 . These findings together provide the first evidence that a defect in the SWI/SNF chromatin remodelling complex of ALL cells can confer GC resistance. 


\section{Asparaginase}

The enzyme asparaginase catalyzes the hydrolysis of asparagine to aspartic acid and is frequently used in the treatment of childhood ALL. In contrast to normal cells, leukemia cells are unable to synthesize the non-essential amino acid asparagine because they lack the enzyme asparagine synthetase (ASNS) which produces asparagine from aspartic acid. The expression of ASNS is low in ALL cells, but ALL cells require asparagine and therefore depend on circulating asparagine. The conversion of L-asparagine to aspartic acid and ammonia by Lasparaginase deprives leukemia cells of circulating asparagine causing amino acid starvation and subsequently apoptosis specifically in ALL cells 80 .

A consistent pattern of gene expression changes measured before and after exposure to Lasparaginase was observed in clinical samples and cell lines of ALL. Notably, the gene expression changes occurred more slowly in the clinical samples ( 24 versus 8 hours). These changes included increase in expression of genes related to amino acid starvation and to proliferation. In contrast to cell lines, increased basal expression of ASNS was not associated with ASP resistance in clinical ALL samples, indicating that ASNS-independent resistance mechanisms are characteristic for primary $\mathrm{ALL}^{37}$.

By analyzing gene expression profiles versus L-asparaginase sensitivity determined in primary ALL blast cells of 126 children (cytotoxicity was measured using the in vitro drug sensitivity MTT-assay), a pattern of 35 genes was identified which was differentially expressed between resistant and sensitive ALL cells. Significantly higher expression of ASNS was found in Lasparaginase-resistant primary ALL ( $<<0.001$ ). Nevertheless, ASNS was not included in the asparaginase resistance profile of 35 genes because the cut-off was $\mathrm{p}<0.000190$.

In a recent investigation ASNS expression levels in mesenchymal cells (MSCs) from bone marrow were 20 times higher than those in ALL cells. This finding is of great importance, as MSCs form the microenvironment in which leukemic cells grow and MSCs may protect ALL cells from L-asparaginase cytotoxicity. The authors suggested that L-asparaginase-like drugs need to be tested in MSCs as well and that concomitant antileukemic therapy may inluence ASNS expression 98 .

\section{HIGH THROUGH-PUT METHODS TO IDENTIFY NEW GENETIC DETERMINANTS INFLUENCING TREATMENT RESPONSE IN ACUTE LEUKEMIA}

DNA microarrays, providing a global view of gene expression, have emerged as an important analytical tool in pharmacogenomics. As technology advances and reliable genome-wide analyses are possible on different levels (SNP, gene expression, microRNA, protein), it will be interesting to combine approaches as has been done with >500k SNPs and expression of about 12,000 genes in a cohort of ALL patients with paired diagnostic and remission samples. Regulatory germline cisSNPs were more likely to be associated when expression was concordant between diagnostic and remission samples 99 .

\section{Gene Expression to Elucidate Genetic Determinants of Antileukemic Drug Resistance}

There has been extensive effort to identify gene expression patterns that differ among molecular subtypes of ALL 100,101,102, and to identify genes associated with drug resistance in ALL 103,104 . Changes in gene expression in tumour cells after exposure to chemotherapy have been studied to help elucidate pathways determining drug response in $\mathrm{ALL}^{36,37}$.

Primary leukemic cells were analyzed for gene expression and in vitro drug sensitivity to four structurally different and widely used antileukemic agents (prednisolone, vincristine, L- 
asparaginase, and daunorubicin). There was minor overlap among resistance genes of the four agents, supporting the concept of multiagent chemotherapy. Importantly, after adjusting for known risk factors (age, WBC, ALL subtype), these resistance patterns correlated to treatment response ${ }^{90}$.

The in vitro sensitivities of primary cells for different antileukemic agents also correlate. When a multi-drug cross-resistance phenotype was used to find gene expression patterns associated with multi-drug resistance in ALL, a gene expression pattern was revealed that was distinct from the collective group of genes associated with single drug resistance, and, importantly, the cross-resistance gene profile further discriminated patients who were at an even higher risk of relapse. The pattern also predicted resistance to MP (which was not among the four antileukemic agents in the discovery cohort), further implicating a multi-drug resistance gene expression profile ${ }^{105}$.

Antileukemic agents induce drug-specific changes in gene expression in ALL cells after in vivo treatment. Gene expression changes in primary ALL cells 42 hours after initial treatment discriminated among three upfront treatments: HDMTX plus MP, LDMTX plus MP, or MP alone. Interestingly, over $80 \%$ of the genes the expression of which altered after combination therapy with MTX and MP did not change significantly after single-agent treatment with these agents; thus the effects of combination therapy are not simply the sum of effects of each single agent ${ }^{36,106}$. Assessing gene expression changes in ALL cells subsequently was used as a readout for screening small molecules for their effects on ALL cells 103,107 . For ALL, as drugassociated gene expression profiles have identified an association of the mTOR inhibitor rapamycin with the GC profile, a potential agent to revert GC resistance may have been identified (see chapter on glucocorticoids) 92 .

The Connectivity Map identified genomic signatures that potentially discern drugs with common mechanisms of action (such as HDAC inhibitors and estrogen receptor modulators), discover unknown mechanisms of actions (for example, gedunin as an HSP90 inhibitor), and identify potential new therapeutics (like the ability of sirolimus to overcome dexamethasone resistance in ALL). Gene expression signatures are often conserved across different cell types and settings (the signature of dexamethasone resistance was defined in bone marrow samples but searched against profiles from the MCF7 breast cancer line). Nevertheless, the small number of cell types also has limitations (the signature of estradiol was not detected in cells that lacked estrogen receptors). Undoubtedly, this initial map will be refined by increasing the number of compounds and using a larger collection of diverse cell lines ${ }^{108}$.

COG investigators identified a gene expression profile related to remission induction failure in T-ALL and potentially useful to identify drug resistance targets. These profiles were also compared to those in cell lines with acquired resistance to L-asparaginase or daunorubicin ${ }^{109}$. In another study, sixteen common SNPs hypothesized to influence response were genotyped in more than 1000 pediatric patients with ALL. The chemokine receptor 5 (CCR5) polymorphism $+246 \mathrm{~A}>\mathrm{G}$ was found to predict minimal residual disease (MRD) on day 8 and day 28 , after adjustment of the $\mathrm{G}$ allele [syntax of "after adjustment" does not parse for me] being more favorable ${ }^{110}$. MRD on day 19 and day 46 were the phenotypes associated with gene expression in another study of approximately 190 pediatric patients; there were 674 and 105 gene probe sets identified as related to MRD day 19 and 46, respectively. CASP8AP2 was identified as a potential marker for treatment stratification 111,112 .

\section{Gene Expression Patterns Associated with Treatment Outcome}

In most cases, the genes identified in expression studies using ALL relapse or event-free survival (EFS) as the phenotype have not yet been independently validated. Conflicting results are likely due to differences in treatments and because many genes have not yet been 
appropriately interrogated for this poly-genetic trait (EFS). However, promising is the consistency in studies of acute leukemias subtypes ne distinct gene expression profiles, and marker genes from profiles suggestive of uenxpected insights into the pathobiology of the disease and as potential new targets for therapeutic intervention. A few drugs targeting these molecular targets are already in early clinical trials (such as imatinib for BCR-ABL positive ALL).

Expression profiles were examined in 35 matched diagnosis/relapse pairs. Early relapse samples were more likely to be similar to their respective diagnostic sample while there was greater divergence in gene-expression patterns among late-relapse pairs. These results suggest that early-relapse results from the emergence of a related clone, characterized by the upregulation of genes mediating cell proliferation. In contrast, late relapse appears to be mediated by diverse pathways initiated by a cell that was not predominant at diagnosis 113 . A loss of heterozygosity $(\mathrm{LOH})$ analysis using the first generation SNP chip was done in ten patients and compared DNA obtained at diagnosis, in remission, and at relapse. Abnormalities were found in eight of the ten cases, and most frequently involved chromosome 9p. In particular LOH included the INK4A locus ${ }^{114}$.

\section{Gene Expression Patterns Associated with Adverse Drug Effects}

To identify genes that may predispose to therapy related AML (t-ML) in children treated for ALL, gene expression was performed in ALL cells from 228 children treated on protocols that included leukemogenic agents such as etoposide, 13 of whom developed t-ML. Several genes whose expression distinguished patients at risk of t-ML were identified, suggesting targets to assess for germline predisposition to treatment-related leukemogenesis 115 . Similarly, another study analyzed about 100k germline SNP for potential association with t-ML in 13 matched cases and 156 unmatched controls. By various strategies, cell adhesion, Wnt signalling, and regulation of actin were identified as novel pathways that may contribute to therapy induced leukemia ${ }^{116}$. The two studies showed an overlap of 54 out of 63 genes in differential gene expression.

To find genetic markers of GC-induced hypertension, genotypes were obtained for 203 candidate polymorphisms in genes previously linked to hypertension or to the pharmacokinetics or pharmacodynamics of antileukemic agents. Patients were evaluated during the 28-day period of prednisone treatment with remission induction of childhood ALL. Of the 602 children with newly diagnosed ALL who were normotensive at diagnosis, 270 $(45 \%)$ developed hypertension during remission induction. None of the putative risk factors (age, sex, race, white blood cell count, risk group, body mass index, or serum creatinine) was associated with hypertension. Polymorphisms in eight genes (CNTNAP2, LEPR, CRHR1, NTAN1, SLC12A3, ALPL, BGLAP, and APOB) were significantly related to GC-induced hypertension $^{117}$.

Another important GC toxicity is osteonecrosis. In addition to age greater than ten years and white race, the vitamin D receptor $(V D R)$ FokI start site CC genotype and the thymidylate synthase (TYMS) low activity $2 / 2$ enhancer repeat genotype were initially identified to predispose to the development of osteonecrosis 118 . Subsequently, twelve polymorphisms in genes putatively predisposing to osteonecrosis were analyzed in patients ten years and older treated with dexamethasone on a single protocol. A PAI-1 polymorphism (rs6092) was associated with risk of osteonecrosis in univariate and multivariate analyses (adjusting for sex, age, and treatment arm). In summary, 21 of 78 (26.9\%) children with PAI-l GA/AA genotypes versus 25 of $214(11.7 \%)$ children with GG genotype, developed osteonecrosis. A genetic variation may contribute to risk of osteonecrosis ${ }^{119}$. Patients tested positive for this variant may be monitored more closely and therapeutic intervention may be initiated more timely. 


\section{THE FUTURE OF PHARMACOGENOMICS}

Clearly pharmacogenomics has great potential to improve the use of antileukemic agents to reduce toxicity and enhance efficacy by guiding optimal treatment selection, dose individualization, and new drug discovery. The identification of genetic determinants of efficacy and toxicity of antileukemia agents in children has the potential to enter routine molecular diagnostics and to prospectively individualize and optimize treatment. Current information likely represents a small fraction of the important genomic determinants for ALL chemotherapy. Moreover, most drug responses are influenced by multiple genes, so polygenetic studies and models will be required to more fully elucidate the genetic determinants of drug response ${ }^{1}$. A major challenge will be to establish optimal treatment approaches by determining how genetic information can be used in conjunction with data on non-genetic causes of inter-patient variability in drug response. In addition, proteomic approaches may augment the discovery process by providing information on post-transcriptional and posttranslational modifications of gene products. Another beneficial application of pharmacogenomics will likely be in the drug-discovery and development process. Genetic profiling and proteomic analysis of tumour and normal tissue should facilitate the discovery of new targets for anticancer drugs and of previously unrecognized genomic determinants of cancer drug resistance and host toxicity. It should be noted that rigorous and systematic quantitation of drug response phenotypes (drug toxicity, drug resistance, and others is often more difficult than is measurement of genome variability. To this end, informed consent should be sought from all patients enrolled on cancer clinical trials so that samples of their genomic DNA (and cancer cell DNA when appropriate) can be obtained for pharmacogenomic studies. Furthermore, protocols should be designed to standardized prospective phenotype measurements for pharmacogenetic studies. ${ }^{120}$ Ideally, these protocols will be designed so that subsequent genomic studies can be performed as new knowledge about candidate genes and new technologies emerge. Together, these approaches should facilitate pharmacogenomic discoveries and their translation to further individualization and optimization of cancer treatment.

Genome variability is an important determinant of drug disposition and effects in children with ALL. It should be recognized, however, that a specific genotype may be important in determining the effects of a medication for one population or disease but not for another. Therefore, pharmacogenomic relations must be extensively validated for each therapeutic indication and in different racial and ethnic groups to ensure accurate assessment of genetic determinants of drug response and to guide translation of pharmacogenomics into widespread clinical practice.

Future studies using pharmacogenomic approaches are necessary to elucidate additional mechanisms of de novo or acquired drug resistance and other important prognostic pharmacogenomic determinants. These discoveries hold great promise for optimizing treatment, for developing more effective antileukemic agents, and for ultimately improving cure rates for patients with ALL and other human cancers.

\section{Acknowledgements}

This work was supported in part by the following National Institutes of Health grants: (R37 CA36401), (R01 CA78224), (U01 GM61393), Cancer Center Support Grant (CA21765), and by the American Lebanese Syrian Associated Charities (WEE); Research grant of the Institut National de la sante et de la recherche medicale (Inserm), Paris, France and the Institut National du Cancer (INCa), Boulogne Bilancourt, France (MHC). 


\section{Reference List}

1. Evans WE, Relling MV. Moving towards individualized medicine with pharmacogenomics. Nature 2004;429:464-468. [PubMed: 15164072]

2. Carlson CS, Eberle MA, Rieder MJ, Smith JD, Kruglyak L, Nickerson DA. Additional SNPs and linkage-disequilibrium analyses are necessary for whole-genome association studies in humans. Nat Genet 2003;33:518-521. [PubMed: 12652300]

3. Hinds DA, Stuve LL, Nilsen GB, Halperin E, Eskin E, Ballinger DG, et al. Whole-genome patterns of common DNA variation in three human populations. Science 2005;307:1072-1079. [PubMed: 15718463]

4. Sachidanandam R, Weissman D, Schmidt SC, Kakol JM, Stein LD, Marth G, et al. A map of human genome sequence variation containing 1.42 million single nucleotide polymorphisms. Nature 2001;409:928-933. [PubMed: 11237013]

5. Risch NJ. Searching for genetic determinants in the new millennium. Nature 2000;405:847-856. [PubMed: 10866211]

6. Cheng Q, Wu B, Kager L, Panetta JC, Zheng J, Pui CH, et al. A substrate specific functional polymorphism of human gamma-glutamyl hydrolase alters catalytic activity and methotrexate polyglutamate accumulation in acute lymphoblastic leukaemia cells. Pharmacogenetics 2004;14:557567. [PubMed: 15284538]

7. Kimchi-Sarfaty C, Oh JM, Kim IW, Sauna ZE, Calcagno AM, Ambudkar SV, et al. A "silent" polymorphism in the MDR1 gene changes substrate specificity. Science 2007;315:525-528. [PubMed: 17185560]

8. Mishra PJ, Humeniuk R, Mishra PJ, Longo-Sorbello GS, Banerjee D, Bertino JR. A miR-24 microRNA binding-site polymorphism in dihydrofolate reductase gene leads to methotrexate resistance. Proc Natl Acad Sci U S A 2007;104:13513-13518. [PubMed: 17686970]

9. Gabriel SB, Schaffner SF, Nguyen H, Moore JM, Roy J, Blumenstiel B, et al. The structure of haplotype blocks in the human genome. Science 2002;296:2225-2229. [PubMed: 12029063]

10. Roses AD. Pharmacogenetics and the practice of medicine. Nature 2000;405:857-865. [PubMed: 10866212]

11. A haplotype map of the human genome. Nature 2005;437:1299-1320. [PubMed: 16255080]

12. Kennedy GC, Matsuzaki H, Dong S, Liu WM, Huang J, Liu G, et al. Large-scale genotyping of complex DNA. Nat Biotechnol 2003;21:1233-1237. [PubMed: 12960966]

13. Kim S, Ruparel HD, Gilliam TC, Ju J. Digital genotyping using molecular affinity and mass spectrometry. Nat Rev Genet 2003;4:1001-1008. [PubMed: 14631360]

14. Ranade K, Chang MS, Ting CT, Pei D, Hsiao CF, Olivier M, et al. High-throughput genotyping with single nucleotide polymorphisms. Genome Res 2001;11:1262-1268. [PubMed: 11435409]

15. Shi MM. Enabling large-scale pharmacogenetic studies by high-throughput mutation detection and genotyping technologies. Clin Chem 2001;47:164-172. [PubMed: 11159763]

16. Syvanen AC. Accessing genetic variation: genotyping single nucleotide polymorphisms. Nat Rev Genet 2001;2:930-942. [PubMed: 11733746]

17. Altshuler D, Daly M, Kruglyak L. Guilt by association. Nat Genet 2000;26:135-137. [PubMed: 11017062]

18. Kwok PY. Genomics. Genetic association by whole-genome analysis? Science 2001;294:1669-1670. [PubMed: 11721042]

19. Tabor HK, Risch NJ, Myers RM. Opinion: Candidate-gene approaches for studying complex genetic traits: practical considerations. Nat Rev Genet 2002;3:391-397. [PubMed: 11988764]

20. Eichler EE, Nickerson DA, Altshuler D, Bowcock AM, Brooks LD, Carter NP, et al. Completing the map of human genetic variation. Nature 2007;447:161-165. [PubMed: 17495918]

21. Scherer SW, Lee C, Birney E, Altshuler DM, Eichler EE, Carter NP, et al. Challenges and standards in integrating surveys of structural variation. Nat Genet 2007;39:S7-15. [PubMed: 17597783]

22. Cappuzzo F, Hirsch FR, Rossi E, Bartolini S, Ceresoli GL, Bemis L, et al. Epidermal growth factor receptor gene and protein and gefitinib sensitivity in non-small-cell lung cancer. J Natl Cancer Inst 2005;97:643-655. [PubMed: 15870435] 
23. Mullighan CG, Goorha S, Radtke I, Miller CB, Coustan-Smith E, Dalton JD, et al. Genome-wide analysis of genetic alterations in acute lymphoblastic leukaemia. Nature 2007;446:758-764. [PubMed: 17344859]

24. Ferrando AA, Look AT. Clinical implications of recurring chromosomal and associated molecular abnormalities in acute lymphoblastic leukemia. Semin Hematol 2000;37:381-395. [PubMed: 11071360]

25. Shaw CJ, Lupski JR. Implications of human genome architecture for rearrangement-based disorders: the genomic basis of disease. Hum Mol Genet 2004;13(Spec No 1):R57-R64. [PubMed: 14764619]

26. Lasko D, Cavenee W, Nordenskjold M. Loss of constitutional heterozygosity in human cancer. Annu Rev Genet 1991;25:281-314. [PubMed: 1687498]

27. Shi L, Reid LH, Jones WD, Shippy R, Warrington JA, Baker SC, et al. The MicroArray Quality Control (MAQC) project shows inter- and intraplatform reproducibility of gene expression measurements. Nat Biotechnol 2006;24:1151-1161. [PubMed: 16964229]

28. Bartel DP. MicroRNAs: genomics, biogenesis, mechanism, and function. Cell 2004;116:281-297. [PubMed: 14744438]

29. Liu CG, Spizzo R, Calin GA, Croce CM. Expression profiling of microRNA using oligo DNA arrays. Methods 2008;44:22-30. [PubMed: 18158129]

30. Altman RB, Klein TE. Challenges for biomedical informatics and pharmacogenomics. Annu Rev Pharmacol Toxicol 2002;42:113-133. [PubMed: 11807167]

31. di BD, Thompson MJ, Gardner TS, Chobot SE, Eastwood EL, Wojtovich AP, et al. Chemogenomic profiling on a genome-wide scale using reverse-engineered gene networks. Nat Biotechnol 2005;23:377-383. [PubMed: 15765094]

32. Gardner TS, di BD, Lorenz D, Collins JJ. Inferring genetic networks and identifying compound mode of action via expression profiling. Science 2003;301:102-105. [PubMed: 12843395]

33. Sauer U, Heinemann M, Zamboni N. Genetics. Getting closer to the whole picture. Science 2007;316:550-551. [PubMed: 17463274]

34. Cheng Q, Yang W, Raimondi SC, Pui CH, Relling MV, Evans WE. Karyotypic abnormalities create discordance of germline genotype and cancer cell phenotypes. Nat Genet 2005;37:878-882. [PubMed: 16041371]

35. Polyak K, Riggins GJ. Gene discovery using the serial analysis of gene expression technique: implications for cancer research. J Clin Oncol 2001;19:2948-2958. [PubMed: 11387368]

36. Cheok MH, Yang W, Pui CH, Downing JR, Cheng C, Naeve CW, et al. Treatment-specific changes in gene expression discriminate in vivo drug response in human leukemia cells. Nat Genet 2003;34:85-90. [PubMed: 12704389]

37. Fine BM, Kaspers GJ, Ho M, Loonen AH, Boxer LM. A genome-wide view of the in vitro response to 1-asparaginase in acute lymphoblastic leukemia. Cancer Res 2005;65:291-299. [PubMed: 15665306]

38. Weinshilboum R. Inheritance and drug response. N Engl J Med 2003;348:529-537. [PubMed: 12571261]

39. Costea I, Moghrabi A, Laverdiere C, Graziani A, Krajinovic M. Folate cycle gene variants and chemotherapy toxicity in pediatric patients with acute lymphoblastic leukemia. Haematologica 2006;91:1113-1116. [PubMed: 16870553]

40. de JR, Hooijberg JH, van Zelst BD, Jansen G, Van Zantwijk CH, Kaspers GJ, et al. Effect of polymorphisms in folate-related genes on in vitro methotrexate sensitivity in pediatric acute lymphoblastic leukemia. Blood 2005;106:717-720. [PubMed: 15797993]

41. Kishi S, Cheng C, French D, Pei D, Das S, Cook EH, et al. Ancestry and pharmacogenetics of antileukemic drug toxicity. Blood 2007;109:4151-4157. [PubMed: 17264302]

42. Rocha JC, Cheng C, Liu W, Kishi S, Das S, Cook EH, et al. Pharmacogenetics of outcome in children with acute lymphoblastic leukemia. Blood 2005;105:4752-4758. [PubMed: 15713801]

43. Relling MV, Hancock ML, Boyett JM, Pui CH, Evans WE. Prognostic importance of 6mercaptopurine dose intensity in acute lymphoblastic leukemia. Blood 1999;93:2817-2823. [PubMed: 10216075]

44. Eichelbaum M, Ingelman-Sundberg M, Evans WE. Pharmacogenomics and individualized drug therapy. Annu Rev Med 2006;57:119-137. [PubMed: 16409140] 
45. Krynetski EY, Schuetz JD, Galpin AJ, Pui CH, Relling MV, Evans WE. A single point mutation leading to loss of catalytic activity in human thiopurine S-methyltransferase. Proc Natl Acad Sci U S A 1995;92:949-953. [PubMed: 7862671]

46. McLeod HL, Krynetski EY, Relling MV, Evans WE. Genetic polymorphism of thiopurine methyltransferase and its clinical relevance for childhood acute lymphoblastic leukemia. Leukemia 2000;14:567-572. [PubMed: 10764140]

47. Weinshilboum RM, Sladek SL. Mercaptopurine pharmacogenetics: monogenic inheritance of erythrocyte thiopurine methyltransferase activity. Am J Hum Genet 1980;32:651-662. [PubMed: 7191632]

48. Yates CR, Krynetski EY, Loennechen T, Fessing MY, Tai HL, Pui CH, et al. Molecular diagnosis of thiopurine S-methyltransferase deficiency: genetic basis for azathioprine and mercaptopurine intolerance. Ann Intern Med 1997;126:608-614. [PubMed: 9103127]

49. Lennard L, Lilleyman JS, Van LJ, Weinshilboum RM. Genetic variation in response to 6mercaptopurine for childhood acute lymphoblastic leukaemia. Lancet 1990;336:225-229. [PubMed: 1973780]

50. Evans WE, Horner M, Chu YQ, Kalwinsky D, Roberts WM. Altered mercaptopurine metabolism, toxic effects, and dosage requirement in a thiopurine methyltransferase-deficient child with acute lymphocytic leukemia. J Pediatr 1991;119:985-989. [PubMed: 1960624]

51. Evans WE, Hon YY, Bomgaars L, Coutre S, Holdsworth M, Janco R, et al. Preponderance of thiopurine S-methyltransferase deficiency and heterozygosity among patients intolerant to mercaptopurine or azathioprine. J Clin Oncol 2001;19:2293-2301. [PubMed: 11304783]

52. Relling MV, Hancock ML, Rivera GK, Sandlund JT, Ribeiro RC, Krynetski EY, et al. Mercaptopurine therapy intolerance and heterozygosity at the thiopurine S-methyltransferase gene locus. J Natl Cancer Inst 1999;91:2001-2008. [PubMed: 10580024]

53. Relling MV, Yanishevski Y, Nemec J, Evans WE, Boyett JM, Behm FG, et al. Etoposide and antimetabolite pharmacology in patients who develop secondary acute myeloid leukemia. Leukemia 1998;12:346-352. [PubMed: 9529129]

54. Relling MV, Rubnitz JE, Rivera GK, Boyett JM, Hancock ML, Felix CA, et al. High incidence of secondary brain tumours after radiotherapy and antimetabolites. Lancet 1999;354:34-39. [PubMed: 10406363]

55. Stanulla M, Schaeffeler E, Flohr T, Cario G, Schrauder A, Zimmermann M, et al. Thiopurine methyltransferase (TPMT) genotype and early treatment response to mercaptopurine in childhood acute lymphoblastic leukemia. JAMA 2005;293:1485-1489. [PubMed: 15784872]

56. Chen ZS, Lee K, Walther S, Raftogianis RB, Kuwano M, Zeng H, et al. Analysis of methotrexate and folate transport by multidrug resistance protein 4 (ABCC4): MRP4 is a component of the methotrexate efflux system. Cancer Res 2002;62:3144-3150. [PubMed: 12036927]

57. Hooijberg JH, Broxterman HJ, Kool M, Assaraf YG, Peters GJ, Noordhuis P, et al. Antifolate resistance mediated by the multidrug resistance proteins MRP1 and MRP2. Cancer Res 1999;59:2532-2535. [PubMed: 10363967]

58. Zeng H, Chen ZS, Belinsky MG, Rea PA, Kruh GD. Transport of methotrexate (MTX) and folates by multidrug resistance protein (MRP) 3 and MRP1: effect of polyglutamylation on MTX transport. Cancer Res 2001;61:7225-7232. [PubMed: 11585759]

59. McGuire JJ, Hsieh P, Coward JK, Bertino JR. Enzymatic synthesis of folylpolyglutamates. Characterization of the reaction and its products. J Biol Chem 1980;255:5776-5788. [PubMed: 6892914]

60. Banerjee D, Mayer-Kuckuk P, Capiaux G, Budak-Alpdogan T, Gorlick R, Bertino JR. Novel aspects of resistance to drugs targeted to dihydrofolate reductase and thymidylate synthase. Biochim Biophys Acta 2002;1587:164-173. [PubMed: 12084458]

61. Chabner BA, Allegra CJ, Curt GA, Clendeninn NJ, Baram J, Koizumi S, et al. Polyglutamation of methotrexate. Is methotrexate a prodrug? J Clin Invest 1985;76:907-912. [PubMed: 2413074]

62. Barredo JC, Synold TW, Laver J, Relling MV, Pui CH, Priest DG, et al. Differences in constitutive and post-methotrexate folylpolyglutamate synthetase activity in B-lineage and T-lineage leukemia. Blood 1994;84:564-569. [PubMed: 7517720] 
63. Masson E, Relling MV, Synold TW, Liu Q, Schuetz JD, Sandlund JT, et al. Accumulation of methotrexate polyglutamates in lymphoblasts is a determinant of antileukemic effects in vivo. A rationale for high-dose methotrexate. J Clin Invest 1996;97:73-80. [PubMed: 8550853]

64. Whitehead VM, Rosenblatt DS, Vuchich MJ, Shuster JJ, Witte A, Beaulieu D. Accumulation of methotrexate and methotrexate polyglutamates in lymphoblasts at diagnosis of childhood acute lymphoblastic leukemia: a pilot prognostic factor analysis. Blood 1990;76:44-49. [PubMed: 1694703]

65. Evans WE, Crom WR, Abromowitch M, Dodge R, Look AT, Bowman WP, et al. Clinical pharmacodynamics of high-dose methotrexate in acute lymphocytic leukemia. Identification of a relation between concentration and effect. N Engl J Med 1986;314:471-477. [PubMed: 3456079]

66. Evans WE, Relling MV, Rodman JH, Crom WR, Boyett JM, Pui CH. Conventional compared with individualized chemotherapy for childhood acute lymphoblastic leukemia. N Engl J Med 1998;338:499-505. [PubMed: 9468466]

67. Hulot JS, Villard E, Maguy A, Morel V, Mir L, Tostivint I, et al. A mutation in the drug transporter gene ABCC2 associated with impaired methotrexate elimination. Pharmacogenet Genomics 2005;15:277-285. [PubMed: 15864128]

68. Rau T, Erney B, Gores R, Eschenhagen T, Beck J, Langer T. High-dose methotrexate in pediatric acute lymphoblastic leukemia: impact of $\mathrm{ABCC} 2$ polymorphisms on plasma concentrations. Clin Pharmacol Ther 2006;80:468-476. [PubMed: 17112803]

69. Krajinovic M, Lemieux-Blanchard E, Chiasson S, Primeau M, Costea I, Moghrabi A. Role of polymorphisms in MTHFR and MTHFD1 genes in the outcome of childhood acute lymphoblastic leukemia. Pharmacogenomics J 2004;4:66-72. [PubMed: 14647408]

70. Aplenc R, Thompson J, Han P, La M, Zhao H, Lange B, et al. Methylenetetrahydrofolate reductase polymorphisms and therapy response in pediatric acute lymphoblastic leukemia. Cancer Res 2005;65:2482-2487. [PubMed: 15781665]

71. Evans WE. Differing effects of methylenetetrahydrofolate reductase single nucleotide polymorphisms on methotrexate efficacy and toxicity in rheumatoid arthritis. Pharmacogenetics 2002;12:181-182. [PubMed: 11927832]

72. Krajinovic M, Costea I, Chiasson S. Polymorphism of the thymidylate synthase gene and outcome of acute lymphoblastic leukaemia. Lancet 2002;359:1033-1034. [PubMed: 11937185]

73. Lauten M, Asgedom G, Welte K, Schrappe M, Stanulla M. Thymidylate synthase gene polymorphism and its association with relapse in childhood B-cell precursor acute lymphoblastic leukemia. Haematologica 2003;88:353-354. [PubMed: 12651279]

74. Costea I, Moghrabi A, Krajinovic M. The influence of cyclin D1 (CCND1) 870A >G polymorphism and CCND1-thymidylate synthase (TS) gene-gene interaction on the outcome of childhood acute lymphoblastic leukaemia. Pharmacogenetics 2003;13:577-580. [PubMed: 12972956]

75. Kager L, Cheok M, Yang W, Zaza G, Cheng Q, Panetta JC, et al. Folate pathway gene expression differs in subtypes of acute lymphoblastic leukemia and influences methotrexate pharmacodynamics. J Clin Invest 2005;115:110-117. [PubMed: 15630450]

76. Sorich MJ, Pottier N, Pei D, Yang W, Kager L, Stocco G, et al. In vivo response to methotrexate forecasts outcome of acute lymphoblastic leukemia and has a distinct gene expression profile. PLoS Med 2008;5:e83. [PubMed: 18416598]

77. Gadner, H.; Masera, G.; Schrappe, M.; Eden, T.; Benoit, Y.; Harrison, C., et al. Leukemia; The Eighth International Childhood Acute Lymphoblastic Leukemia Workshop ('Ponte di legno meeting') report; Vienna, Austria. April 27-28, 2005; 2006. p. 9-17.

78. Kager L, Lion T, Attarbaschi A, Koenig M, Strehl S, Haas OA, et al. Incidence and outcome of TCF3PBX1-positive acute lymphoblastic leukemia in Austrian children. Haematologica 2007;92:15611564. [PubMed: 18024406]

79. Dulucq S, St-Onge G, Gagne V, Ansari M, Sinnett D, Labuda D, et al. DNA variants in the dihydrofolate reductase gene and outcome in childhood ALL. Blood 2008;111:3692-3700. [PubMed: 18096764]

80. Pui CH, Evans WE. Treatment of acute lymphoblastic leukemia. N Engl J Med 2006;354:166-178. [PubMed: 16407512] 
81. Ausserlechner MJ, Obexer P, Bock G, Geley S, Kofler R. Cyclin D3 and c-MYC control glucocorticoid-induced cell cycle arrest but not apoptosis in lymphoblastic leukemia cells. Cell Death Differ 2004;11:165-174. [PubMed: 14576768]

82. Compton MM, Caron LA, Cidlowski JA. Glucocorticoid action on the immune system. J Steroid Biochem 1987;27:201-208. [PubMed: 3501039]

83. Schmidt S, Rainer J, Ploner C, Presul E, Riml S, Kofler R. Glucocorticoid-induced apoptosis and glucocorticoid resistance: molecular mechanisms and clinical relevance. Cell Death Differ 2004;11 (Suppl 1):S45-S55. [PubMed: 15243581]

84. Dordelmann M, Reiter A, Borkhardt A, Ludwig WD, Gotz N, Viehmann S, et al. Prednisone response is the strongest predictor of treatment outcome in infant acute lymphoblastic leukemia. Blood 1999;94:1209-1217. [PubMed: 10438708]

85. Lauten M, Matthias T, Stanulla M, Beger C, Welte K, Schrappe M. Association of initial response to prednisone treatment in childhood acute lymphoblastic leukaemia and polymorphisms within the tumour necrosis factor and the interleukin-10 genes. Leukemia 2002;16:1437-1442. [PubMed: 12145682]

86. Hongo T, Yamada S, Yajima S, Watanabe C, Fujii Y, Kawasaki H, et al. Biological characteristics and prognostic value of in vitro three-drug resistance to prednisolone, $\mathrm{L}$-asparaginase, and vincristine in childhood acute lymphoblastic leukemia. Int J Hematol 1999;70:268-277. [PubMed: 10643153]

87. Kaspers GJ, Veerman AJ, Pieters R, Van Zantwijk CH, Smets LA, van Wering ER, et al. In vitro cellular drug resistance and prognosis in newly diagnosed childhood acute lymphoblastic leukemia. Blood 1997;90:2723-2729. [PubMed: 9326239]

88. Zhou J, Cidlowski JA. The human glucocorticoid receptor: one gene, multiple proteins and diverse responses. Steroids 2005;70:407-417. [PubMed: 15862824]

89. Norman M, Hearing SD. Glucocorticoid resistance - what is known? Curr Opin Pharmacol 2002;2:723-729. [PubMed: 12482737]

90. Holleman A, Cheok MH, den Boer ML, Yang W, Veerman AJ, Kazemier KM, et al. Gene-expression patterns in drug-resistant acute lymphoblastic leukemia cells and response to treatment. N Engl J Med 2004;351:533-542. [PubMed: 15295046]

91. Pottier N, Cheok MH, Yang W, Assem M, Tracey L, Obenauer JC, et al. Expression of SMARCB1 modulates steroid sensitivity in human lymphoblastoid cells: identification of a promoter SNP that alters PARP1 binding and SMARCB1 expression. Hum Mol Genet 2007;16:2261-2271. [PubMed: 17616514]

92. Wei G, Twomey D, Lamb J, Schlis K, Agarwal J, Stam RW, et al. Gene expression-based chemical genomics identifies rapamycin as a modulator of MCL1 and glucocorticoid resistance. Cancer Cell 2006;10:331-342. [PubMed: 17010674]

93. Cheok MH, Pottier N, Yang W, Assem M, Panetta JC, Pei D, et al. The SWI/SNF-chromatinremodeling complex is a determinant of glucocorticoid resistance in acute lymphoblastic leukemia. 2008submitted

94. Tissing WJ, den Boer ML, Meijerink JP, Menezes RX, Swagemakers S, van der Spek PJ, et al. Genomewide identification of prednisolone-responsive genes in acute lymphoblastic leukemia cells. Blood 2007;109:3929-3935. [PubMed: 17218380]

95. Ostlund Farrants AK, Blomquist P, Kwon H, Wrange O. Glucocorticoid receptor-glucocorticoid response element binding stimulates nucleosome disruption by the SWI/SNF complex. Mol Cell Biol 1997;17:895-905. [PubMed: 9001244]

96. Trotter KW, Archer TK. Reconstitution of glucocorticoid receptor-dependent transcription in vivo. Mol Cell Biol 2004;24:3347-3358. [PubMed: 15060156]

97. Wallberg AE, Neely KE, Hassan AH, Gustafsson JA, Workman JL, Wright AP. Recruitment of the SWI-SNF chromatin remodeling complex as a mechanism of gene activation by the glucocorticoid receptor tau1 activation domain. Mol Cell Biol 2000;20:2004-2013. [PubMed: 10688647]

98. Iwamoto S, Mihara K, Downing JR, Pui CH, Campana D. Mesenchymal cells regulate the response of acute lymphoblastic leukemia cells to asparaginase. J Clin Invest 2007;117:1049-1057. [PubMed: 17380207] 
99. French D, Yang W, Hamilton LH, Neale G, Fan Y, Downing JR, et al. Concordant gene expression in leukemia cells and normal leukocytes is associated with germline cis-SNPs. PLoS ONE 2008;3:e2144. [PubMed: 18478092]

100. Golub TR, Slonim DK, Tamayo P, Huard C, Gaasenbeek M, Mesirov JP, et al. Molecular classification of cancer: class discovery and class prediction by gene expression monitoring. Science 1999;286:531-537. [PubMed: 10521349]

101. Ross ME, Zhou X, Song G, Shurtleff SA, Girtman K, Williams WK, et al. Classification of pediatric acute lymphoblastic leukemia by gene expression profiling. Blood 2003;102:2951-2959. [PubMed: 12730115]

102. Yeoh E-J, Ross ME, Surtleff SA, Williams WK, Patel D, Mahfouz R, et al. Classification, subtype discovery, and prediction of outcome in pediatric acute lymphoblastic leukemia by gene expression profiling. Cancer Cell 2002;1:133-143. [PubMed: 12086872]

103. Evans WE, Guy RK. Gene expression as a drug discovery tool. Nat Genet 2004;36:214-215. [PubMed: 14988717]

104. Relling MV, Dervieux T. Pharmacogenetics and cancer therapy. Nat Rev Cancer 2001;1:99-108. [PubMed: 11905809]

105. Lugthart S, Cheok MH, den Boer ML, Yang W, Holleman A, Cheng C, et al. Identification of genes associated with chemotherapy crossresistance and treatment response in childhood acute lymphoblastic leukemia. Cancer Cell 2005;7:375-386. [PubMed: 15837626]

106. Golub TR. Mining the genome for combination therapies. Nat Med 2003;9:510-511. [PubMed: 12724758]

107. Stegmaier K, Ross KN, Colavito SA, O’Malley S, Stockwell BR, Golub TR. Gene expression-based high-throughput screening(GE-HTS) and application to leukemia differentiation. Nat Genet 2004;36:257-263. [PubMed: 14770183]

108. Lamb J, Crawford ED, Peck D, Modell JW, Blat IC, Wrobel MJ, et al. The Connectivity Map: using gene-expression signatures to connect small molecules, genes, and disease. Science 2006;313:1929-1935. [PubMed: 17008526]

109. Winter SS, Jiang Z, Khawaja HM, Griffin T, Devidas M, Asselin BL, et al. Identification of genomic classifiers that distinguish induction failure in T-lineage acute lymphoblastic leukemia: a report from the Children's Oncology Group. Blood 2007;110:1429-1438. [PubMed: 17495134]

110. Davies SM, Borowitz MJ, Rosner GL, Ritz K, Devidas M, Winick N, et al. Pharmacogenetics of minimal residual disease response in children with B-precursor acute lymphoblastic leukemia: a report from the Children's Oncology Group. Blood 2008;111:2984-2990. [PubMed: 18182569]

111. Flotho C, Coustan-Smith E, Pei D, Iwamoto S, Song G, Cheng C, et al. Genes contributing to minimal residual disease in childhood acute lymphoblastic leukemia: prognostic significance of CASP8AP2. Blood 2006;108:1050-1057. [PubMed: 16627760]

112. Flotho C, Coustan-Smith E, Pei D, Cheng C, Song G, Pui CH, et al. A set of genes that regulate cell proliferation predicts treatment outcome in childhood acute lymphoblastic leukemia. Blood 2007;110:1271-1277. [PubMed: 17456722]

113. Bhojwani D, Kang H, Moskowitz NP, Min DJ, Lee H, Potter JW, et al. Biologic pathways associated with relapse in childhood acute lymphoblastic leukemia: a Children's Oncology Group study. Blood 2006;108:711-717. [PubMed: 16822902]

114. Irving JA, Bloodworth L, Bown NP, Case MC, Hogarth LA, Hall AG. Loss of heterozygosity in childhood acute lymphoblastic leukemia detected by genome-wide microarray single nucleotide polymorphism analysis. Cancer Res 2005;65:3053-3058. [PubMed: 15833833]

115. Bogni A, Cheng C, Liu W, Yang W, Pfeffer J, Mukatira S, et al. Genome-wide approach to identify risk factors for therapy-related myeloid leukemia. Leukemia 2006;20:239-246. [PubMed: 16341039]

116. Hartford C, Yang W, Cheng C, Fan Y, Liu W, Trevino L, et al. Genome scan implicates adhesion biological pathways in secondary leukemia. Leukemia 2007;21:2128-2136. [PubMed: 17673902]

117. Kamdem LK, Hamilton L, Cheng C, Liu W, Yang W, Johnson JA, et al. Genetic predictors of glucocorticoid-induced hypertension in children with acute lymphoblastic leukemia. Pharmacogenet Genomics 2008;18:507-514. [PubMed: 18496130] 
118. Relling MV, Yang W, Das S, Cook EH, Rosner GL, Neel M, et al. Pharmacogenetic risk factors for osteonecrosis of the hip among children with leukemia. J Clin Oncol 2004;22:3930-3936. [PubMed: 15459215]

119. French D, Hamilton LH, Mattano LA Jr, Sather HN, Devidas M, Nachman JB, et al. A PAI-1 (SERPINE1) polymorphism predicts osteonecrosis in children with acute lymphoblastic leukemia: a report from the Children's Oncology Group. Blood 2008;111:4496-4499. [PubMed: 18285546]

120. Evans WE, McLeod HL. Pharmacogenomics--drug disposition, drug targets, and side effects. N Engl J Med 2003;348:538-549. [PubMed: 12571262] 


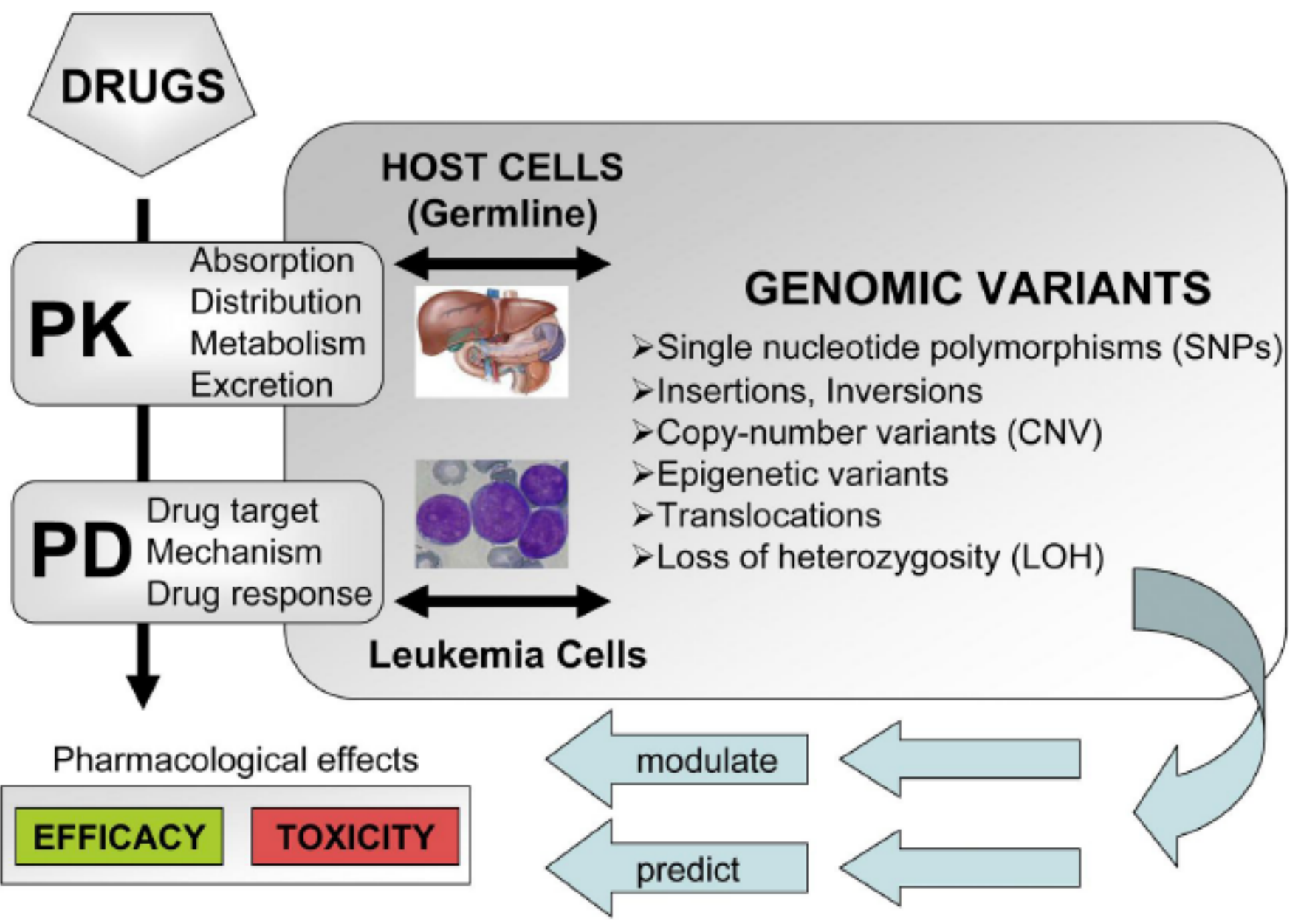

Figure 1. 
Table 1

Websites relevant to pharmacogenetics.

\begin{tabular}{|c|c|}
\hline Name & Website \\
\hline Human Genome Project (HGP) & www.ornl.gov/TechResources/Human_Genome/home.html \\
\hline UCSC Genome Browser & http://genome.ucsc.edu/ \\
\hline The Sanger Institute & www.sanger.ac.uk/ \\
\hline Gene Expression Omnibus (NCBI) & www.ncbi.nlm.nih.gov/projects/geo/ \\
\hline $\mathrm{dbSNP}(\mathrm{NCBI})$ & www.ncbi.nlm.nih.gov/SNP/ \\
\hline International HapMap Project & snp.cshl.org/ \\
\hline Weizmann Institute GeneCards & bioinfo.weizmann.ac.il/cards/ \\
\hline OMIM Catalog of Genetic Diseases & www.ncbi.nlm.nih.gov/sites/entrez?db=omim \\
\hline Glossary of Genetic Terms (NIH) & www.nhgri.nih.gov/DIR/VIP/Glossary \\
\hline RxList - The Internet Drug Index & www.rxlist.com/ \\
\hline PCS Performance Drug List & www.druglist.com/ \\
\hline P450 (CYP) Allele Nomenclature Committee & www.imm.ki.se/cypalleles/ \\
\hline PharmGKB:The Pharmacogenetics and Pharmacogenomics Knowledge Base & www.pharmgkb.org/ \\
\hline NIGMS:Pharmacogenetics Research Network & www.nigms.nih.gov/Initiatives/PGRN \\
\hline The Pharmacogenomics Journal & www.nature.com/tpj/index.html \\
\hline
\end{tabular}

